\title{
IJBF CORPORATE SPIN-OFFS, THEIR PRICE REACTIONS AND DETERMINANTS IN MALAYSIA
}

\author{
Chung-Sin Yoon and Mohamed Ariff \\ Alan Yoon Associates and Bond University, \\ Australia
}

\begin{abstract}
Spin-off as a form of financial restructuring has been examined in the US and the UK but not in other markets. This is a first study outside those markets. The evidence from a sample of 85 spin-off cases in Malaysia reveals that both the parent and the spin-off company stocks gain significant positive abnormal returns: parent firms earn smaller value while the spin-off firm gains substantially, much greater than is documented in other markets. Examining the factors correlated with the size of the spin-off effect, we find the abnormal returns are positively correlated with market capitalization and negatively correlated with age. The larger is the company or the newer is the company the greater is the magnitude of the positive abnormal returns.
\end{abstract}

JEL Classification: G14

Key words: Spin-offs, Restructuring, Emerging Markets, Tax Motivation, Size, and Age.

\section{Introduction to spin-off}

This paper reports new findings from a study on corporate spin-off phenomenon, an increasingly popular financial restructuring method, and their determinants in an emerging economy. While few studies exist on the spin-off price effect in the US and the UK markets, this is the first study of its kind outside those countries, which also tests if certain firm characteristics are correlated with price behavior at the announcement period. Hence, this paper is motivated to fill a gap in the literature to contribute to studies of financial restructuring. Restructuring is becoming popular also for the other reason that firms in recent years are moving away from the conglomeration model to focused business model

* Editorial Note: This paper was one of three best papers selected by the then Editor of $I J B F$ at the FMA-AFA 2005 conference. The co-author of this paper commenced duties as co-editor of $I J B F$ in 2007 , and he did not have any part in the selection/review of this paper 
to create value in a more competitive business environment of the last two decades. Understanding the factors driving this phenomenon in a developing economy context will be useful for corporate strategy and financing matters.

The growth of the emerging markets in such economies has received much attention in the past few years: see Barry, Peavy and Rodriguez (1997). Investors have been attracted to the potential for high returns along with diversification benefits of such markets. ${ }^{1}$ Managers and trustees of Australian, US and UK pension funds have begun for the first time to commit portions of their pension assets to emerging market debt and equity securities. The unique characteristics of emerging markets are helping academics to better understand the development and application of appropriate financial management techniques in companies operating in such environment. This is another aspect of this paper to provide an understanding of the forces affecting spin-offs.

The earliest recorded spin-off case in this paper was in 1970 relating to a popular conglomerate namely the Magnum Corporation. Since then, there have been 125 spin-offs. Spin-off is occurring at increasing frequency in several Asian countries as public-listed firms have come of age over the last four decades, and are creating more focused businesses by spinning-off from their existing firms. The capital market in Malaysia is classified by the World Bank as an emerging market for the simple reason that per capita income in this country is less that the threshold ${ }^{2}$ for warranting a classification as developed. However, market specialists such as Dow Jones and others have included this capital market as among the 20 plus markets in the world for international diversification of investments. There are about 900 plus firms on the Bursa Malaysia, the single Malaysian exchange for the capital market. ${ }^{3}$ Of these, most firms are listed on the main board while 300 plus firms are listed on the second board. In total, these companies have market capitalization of over US\$ 160 billion. There is also a bond market with a capitalization equal to about 95 percent of the GDP, which would place this bond market as the fourth largest in Asia. The economy is an industrialized economy with industrial output accounting for 35 percent of the output.

For many years, Malaysia has become the most open economy among the developing countries to foreign investment, international trade and also the ex-

\footnotetext{
${ }^{1}$ Based on the IFC's Emerging Markets Data Base for a recent period, a commonly held view is emerging stock markets are characterized by high returns and high volatility. Malaysian market is such a market and is ranked among the top-20 or thereabout, and is among the 65 -odd emerging markets. It is ranked in the financial press as being among the top five in terms of its desirability for cross-border investments.

${ }^{2}$ The World Bank defines a developing country as one having a per capita GNP that would place it in the lower or middle-income category; a developing country had an annual per capita GNP less than about US\$10,000. Capital markets in such a country would be named an emerging market. The capital market is ranked by OECD in 1999 report as among the top-20 investible market.

${ }^{3}$ Two stock exchanges, the then Kuala Lumpur Stock Exchange (KLSE) and Malaysian Exchange of Securities Dealing and Automated Quotation Bhd (MESDAQ) had merged to form Bursa Malaysia. KLSE was incorporated in 1976 and MESDAQ was incorporated in 1997.
} 
tent of multinational presence. ${ }^{4}$ It was quick to recognize the powerful role that foreign investors could play in fuelling export-led growth, and it is also wellplaced to attract such investment during the years of regional structural adjustment taking place in the late 1980s. Partly as a result of FDI inflows, this economy was among the world's fastest growing economies prior the 1997 financial crisis. In the wake of the financial crisis which swept through the Asian region, ${ }^{5}$ it is useful to note the new focus of the various Asian countries in their economic development approach. In all the four countries - Malaysia, Indonesia, Philippines and Thailand - development strategies now includes a selective approach to investment promotion with a clearly circumscribed role for foreign direct investors. Such partial openness allows foreign firms to contribute to rapid economic growth driven by exports, but these days countries have tended to lessen the welcome to short term capital flows, which has been the underlying cause of the economic flap in the late 1990s.

The legal concept of tax-free Spin-off can be found in the Inland Revenue Service (IRS) code Section 355 of the Securities and Exchange Commission Tax Code and the Treasury regulations Section 1, 355-2 in the U.S. ${ }^{6}$ There was an amendment to the legal framework after 1969 to restrict tax avoidance. In fact, after the Tax Reform Act of 1986, a spin-off or other divisive reorganization is the only way a company can distribute appreciated property to shareholders without incurring a corporate-level tax. An added appeal is that corporations have considerable latitude in reporting spin-offs in their financial statements. The regulation on spin-off became more pronounced in Europe recently as spin-offs became more popular during the 1990s. In Malaysia, legal representation initially rested on the Capital Issues Committee and the Foreign Issues Committee. Since 1996, spin-off is regulated under the Arrangements and Reconstruction Section of the Companies Act 1965.

Following the procedure of companies going for listing, a spin-off application is reviewed by the Securities Commission, Companies Commission and the Bursa Malaysia as the regulators. ${ }^{7}$ Spin-offs are also regulated under Section 176 of the

\footnotetext{
${ }^{4}$ New foreign and domestic investment played a significant role in the transformation of this economy. Manufacturing share increased from $13.9 \%$ (1970) to 34\% (2005) as agriculture declined from $42.7 \%$ to under 7\% over the same period: see 2005 Bank Negara Malaysia Annual Report.

${ }^{5}$ After nearly two decades of strong economic growth averaging 8.7 percent annually, the financial crisis had long-lasting impact by halving the growth prospect, when the regional financial crisis of 1997-8 swept the region. The GDP suffered a sharp 7.5\% contraction in 1998: it rebounded in 1999 to grow by $5.6 \%$.

${ }^{6}$ IRS Section 355 includes four key requirements for tax-free treatment: Controlled corporation; Securities distribution; Active businesses; and Not a distribution device. Treasury regulations Section 1, 355-2 adds two additional requirements: Business purpose; and Continuity of interest. See Appendix A for details.

${ }^{7}$ Prior to 1995, Capital Issues Committee (CIC) and the Foreign Issues Committee were reviewing. CIC was set up in 1968 by the Minister of Finance to ensure an orderly development of the capital market by regulating the issue of securities by public companies and the listing of such securities on Bursa Malaysia including spin-offs. See the requirements for spin-offs in Appendix A.
} 
Companies Act. In any scheme of arrangement or reconstruction which results in a transfer of assets or undertakings of a foreign incorporated company to Malaysia, the Securities Commission requires that the entries in the books of accounts of "mirror company" comply with the provision of Section 60 of the Companies Act.

The listing of spin-off subsidiary and/or associated companies of a listed holding company could be considered if the pretax profits and net tangible assets of the subsidiary and/or an associated company to be listed should not account for more than 35 percent respectively of the consolidated pretax profits and net tangible assets of the group in the previous five years (Main Board listing) or three years (Second Board listing). The threshold level of after-tax profits and/or net tangible asset contribution for the listing of subsidiary and/or associated companies has been raised from 35.5 percent to 50 percent from 1997 . Another consideration is the parent company excluding the subsidiary and/or associated company to be listed and existing listed subsidiary and/or associated companies should on its own meet Securities Commission's requirements for listing as if it were a new company seeking listing.

The applicant subsidiary and or associated company should also be involved in a particular business of its own with profits able to meet Securities Commission's criteria for listing with respect to profit track record and future prospects. The relationship between the subsidiary and/or associated company seeking listing and the other companies within the group, including the holding company, should not give rise to intra-group competition or conflict of interest situation. The subsidiary and/or associated company to be listed should demonstrate that it is not overly dependent on the other companies with the group including the holding company, in term of its operations, including purchases and sales of goods, management policies and finance.

There has been no Capital Gains Tax on share disposal in this economy. However, an acquisition of shares in a real property company shall be deemed to be an acquisition of chargeable assets, and where such shares are disposed of shall attract Real Property Gains Tax (RPGT) - Schedule 2, Section 34A RPGT Act (1976). It is difficult to rely on Section 17.1 (c) to claim exemption for this RPGT. After 1997, it is not possible to utilize the "bonus shares"8 approaches to exempt RPGT on share disposal of real property companies.

\section{Literature on spin-off cases}

It is pertinent to review a set of literature in this section in order to undertake this study. Earlier theories on capital market research are relevant to this study as are also the specific theories, methods applied and the variables used in studies of

${ }^{8}$ It was possible to use distribution of bonus shares as consideration to save RPGT on selling of land together with the real property companies before 1977 . 
Table 1: A summary of relevant literature and variables on spin-off

\begin{tabular}{|c|c|c|}
\hline 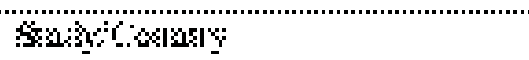 & 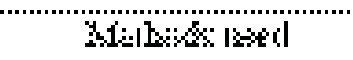 & muilislis:s \\
\hline 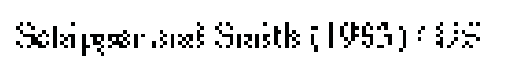 & 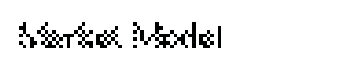 & 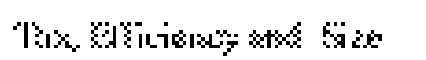 \\
\hline 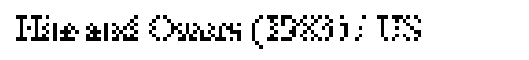 & 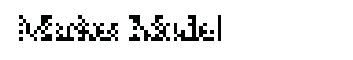 & 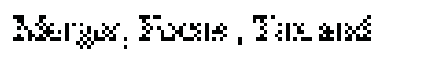 \\
\hline 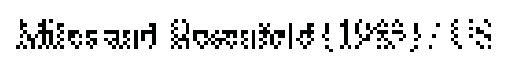 & t: & $s x x$ \\
\hline 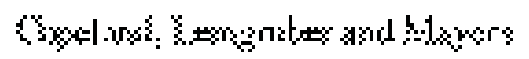 & 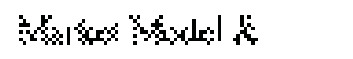 & 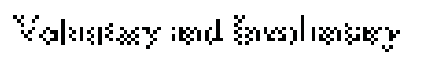 \\
\hline$(13 * 7) ;\}$ & 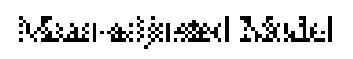 & 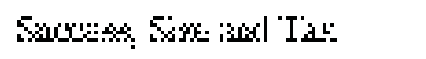 \\
\hline 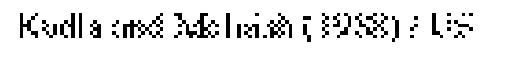 & 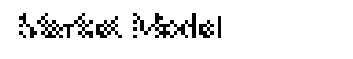 & \\
\hline 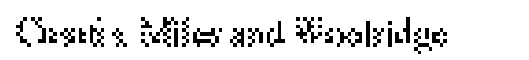 & 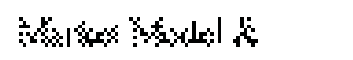 & 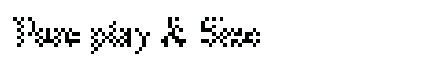 \\
\hline (19\%s)!: $: \mathrm{s}$ & 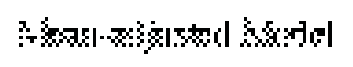 & sherges \\
\hline 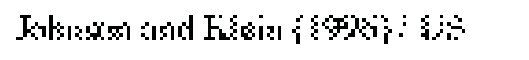 & A*r: Madel & \\
\hline 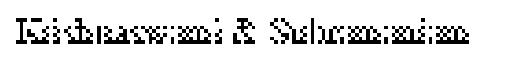 & Marses Mandel & 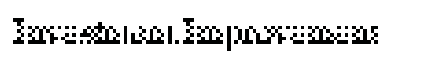 \\
\hline (19)\%: $: \leqslant$ & & 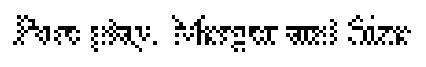 \\
\hline 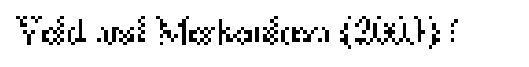 & 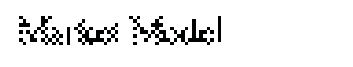 & \\
\hline 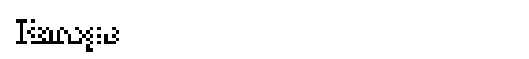 & & GW \\
\hline
\end{tabular}

spin-off case in this literature: Table 1 is a summary of existing literature on spinoff. Hence we review both sets of ideas in this section.

In all there are 11 published studies on spin-off. Most of them, in fact ten, are in the US markets. There is one study in the European market. These authors applied the very common method of estimating the abnormal price behavior measured as abnormal returns around the time of announcements of the spin-off. They all reported significant abnormal returns to this event both in the US and Europe. Those studies also examined a number of variables listed in the last column in the table to verify if these factors are correlated with the observed price behavior. Broadly, in these matured markets, these variables have been found to be significantly correlate with the price change behavior. These studies are limited to spinoff in different legal environments within matured market places. It is unknown if the factors associated with the event are also likely to be correlated with price change behavior in emerging market chosen for this study. The relevant theories to be reviewed from broader literature are itemized here.

1) Valuation as in Hearth and Zaima (1986) and Leshchinski (2002).

2) Agency theory as in Jensen and Meckling (1976).

3) Wealth Transfer as in Galai and Masulis (1976) and Maxwell and Rao (2003).

4) Clientele as in Vijh (1994) and Schnabel (1992).

5) Divergence of Opinion hypothesis as in Miller (1977).

6) Information Asymmetry as in Habib, Johnson and Naik (1997), 
Krishnaswami and Subramaniam (1999) and Veld and Merkoulova (2003).

Empirical tests on the Spin-offs events have confirmed information content of the news of spin-off had effects on share prices in terms of cumulative abnormal returns (CAR). The seven theoretical ideas prevailing about the value of the firm for the study of the management decision effect from spin-off are relevant. ${ }^{9}$ The Market Model is the most common research model used in the previous studies as shown in Table 1 while variables such as Tax, Size and Focus are the most common variables analyzed in the context of these theoretical ideas.

\section{Data, variables and methodology}

The data for this study are from the SCANS data base of security prices for the Kuala Lumpur market. The period covered in this study is over a 23 -year period, where we found 125 spin-offs. Of these we selected 85 spin-off cases using the criteria: both firms must have price history of at least five years; the thin-trading problem is minimal in that the daily price observations are complete; that the firms are local companies. The stock index used is the value-weighted composite index for this market, and the stock returns are computed after adjustments for capitalization and dividends. We selected 85 non-spin-off firms matched by industry and firm size to form a portfolio of firms not affected by spin-off to test if the spin-off sample is different from the non-spin-off as a robustness method to the usual risk-adjusted methods applied in this type of studies. No other studies used the matched sample procedure. The event impact is estimated over a 100 and +50 days. This length of the test window is longer on account of the longer period over which the spin-off-related regulatory decisions are made in this market.

Sharpe (1963) developed the standard form of the general equilibrium relationship of asset returns now known as the Market Model (see Equation 1). It is a statistical model, which relates the return of any given security to the return of the market portfolio. Considering the information content of spin-off studies with daily data, the event of interest will be the spin-off announcement and the analysis period consists of a defined period of price information around the announcement day. This would permit an examination of the price change, if any, to be statistically tested, for the selected periods surrounding the events. The analysis period in this event study is defined as -100 to +50 days around the announcement day.

Notation and time line are defined to facilitate the measurement and analysis

\footnotetext{
${ }^{9}$ Despite the widespread use of the named variables in this section, there is still no agreement among the researchers on the factors influencing the Spin-off effect. We place on record this list as the possible starting point for this study.
} 
of abnormal returns. Consistent with event study methods (see Brown and Warner, 1985 for example). Defining $t=0$ as the event date, then $t=-100$ days to $t=+50$ days represent the event window for analysis. The rate of returns over each day is computed for each of the parent and the spin-off firms. From each of the daily returns, a factor is subtracted as systematic return (to be explained later as riskadjusted; market adjusted; matched sample adjusted) to adjust the gross returns of the days for market-wide impacts as well as risk-adjustment effects. For example, we apply the Market Model of Sharpe to derive the risk-adjusted returns in two steps. In the first step, the market Model parameters $\alpha_{\mathrm{j}}$ and $\beta_{\mathrm{j}}$ for each parent firm are estimated using monthly stock returns $\left(\mathrm{R}_{\mathrm{jt}}\right)$ and monthly market returns $\left(\mathrm{R}_{\mathrm{mt}}\right)$ from market index using the model:

$$
\mathrm{R}_{\mathrm{jt}}=\alpha_{\mathrm{j}} \text { and } \beta_{\mathrm{j}} \mathrm{R}_{\mathrm{mt}}+\mathrm{e}_{\mathrm{jt}}
$$

The abnormal returns to each of the event for the parent company are estimated as in Equation 2:

$$
\mathrm{AR}_{\mathrm{jt}}=\mathrm{R}_{\mathrm{jt}}-\alpha_{\mathrm{j}}-\beta_{\mathrm{j}} \mathrm{R}_{\mathrm{mt}}
$$

Where, AR is the abnormal return over -100 to +50 days with day 0 being the event date when announcement of spin-off is made. The abnormal returns are then cumulated over a given window of time to measure the total impact of the event over a period prior and after-the-event date.

This is the standard methodology followed in all event studies; hence the individual formulas are not reproduced here. One thing is need to be explained in the case of matched sample. We estimate the returns for a matched sample of companies as the gross returns over the test window of -100 and +50 days. Most spun-off companies took 2-3 months to list their companies after announcing to the public: there was a case of 4 years.

To adjust the market-wide and risk-difference-effect, we subtract these returns from the spin-off case returns so that the abnormal returns of the spin-off could be tested. We cumulate the abnormal returns over different time periods as the Cumulative Abnormal Returns or CARs. Again this method is well-entrenched in event study process. The CARs are then used in the regression to test if the firm-specific variables suggested in the literature in fact are correlated with the price change measured as CARs.

The study adopts three different models in the estimation of the abnormal return as follows:

1)Risk-adjusted Market Model,

2)Market-adjusted Market Model, and

3)Control sample adjusted Market Model.

In the controlled sample model, we match for each spin-off case, another 
firm that is not spin-off case in the same industry with approximately the same asset size. Since the accuracy of our estimates are subject to a number of unknown variables, a matched sample is perhaps a better method to see the underlying difference, in case the traditional methods shown as (1) and (2) are prone to error in the emerging market. The return observations from $t=-63$ months to $t=-3$ months are used to estimate the Market Model parameters $\alpha$ and $\beta$ for the parent firm: parent firm's beta is needed to compute the risk-adjusted returns along with the alpha on a daily basis. ${ }^{10}$ The alpha, $\alpha$, measures the unexplainable performance relative to the market model. The, $\beta$, beta is the slope of the characteristic line estimated using the monthly data. As $\alpha$ is estimated from monthly returns data $\alpha_{\mathrm{m}}$ needs to be recomputed as daily alpha $\alpha_{\mathrm{d}}$ as in:

$$
\alpha_{\mathrm{d}}=\left(1+\alpha_{\mathrm{m}}\right)^{1 / 22}-1
$$

The $\alpha_{d}$ is the alpha specified in Equation 2 in an earlier paragraph.

The main hypotheses are developed here are now explained. There are two main hypotheses tested using three different methods of computing the abnormal and CARs. The Hypotheses 1 is as follows: Null; The market value of the postspin-off companies in the period following the announcement of spin-offs is the same as the pre-spin-off entities. This result would suggest that there is no wealth effect from the announcement of spin-offs after the announcement is made but prior to the court decision about asset transfers.

If the null hypothesis is rejected if the observed abnormal return is greater for the post-spin-off period than in the pre-spin-off entity during the analysis period, this means that there is wealth effect created by spin-offs. This will be measured using the three methods of computations.

Hypotheses 2: Null; The selected firm-related variables and the CARs from the event are not significantly correlated: the variables selected are tax, focus, age and market capitalization. If the result supports the null that would suggest that the selected variables are not at all likely to determine the size of the abnormal price effect. Rejection of the null hypothesis would reveal, as has been the case in the U.S. and European studies, the firm characteristics are likely to determine the size of the price effect measured as the CARs.

There are four subsidiary hypotheses to be tested as well. These relate to the individual variable's correlation with the CARs. The magnitude of the capital market reaction to the spin-off announcement depends on the size of the spin-off company in relation to the size of the parent company before spin-off. The longer is the age of the parent company at spin-off time, the larger is the wealth effect.

\footnotetext{
${ }^{10}$ Despite the widespread use of the named variables in this section, there is still no agreement among the researchers on the factors influencing the Spin-off effect. We place on record this list as the possible starting point for this study.
} 
Tax factor is a significant determinant of the corporate spin-off price effect. Finally, improved focus is significantly correlated with the corporate spin-off price effect. A priori, these are the expected results, based on the priors from the 11 studies referred to in an earlier section. Given the institutional differences in the tested market, it may be that some of these results may be otherwise than hypothesized.

For the regression model, the dependent variables are the various CARs over selected intervals. The CAR is then regressed against the independent variables:

$$
\operatorname{CAR}_{\mathrm{j}}=\alpha_{0}+\alpha_{1} \text { Focus }_{\mathrm{j}}+\alpha_{2} \operatorname{Tax}_{\mathrm{j}}+\alpha_{3} \operatorname{Age}_{\mathrm{j}}+\alpha_{4} \operatorname{Size}_{\mathrm{j}}+\epsilon_{\mathrm{j}} \ldots \ldots .
$$

The independent variables are suggested by the literature. Focus is the variable that suggests that firms separating a spin-off to create a more focused business. The tax staus is indicated by the amount of tax benefit from the spinoff case. Age is the length of time the parent has been in business to the date of the spin-off event while the Size is the market capitalization of the firm.

\section{Findings and discussion}

\section{A: Descriptive Statistics}

In Table 2, the descriptive statistics are presented on the abnormal returns of spin-off parent companies. There are three sets of numbers, for the 85 observations, making a total of 255 data points on the spin-off companies. There is a corresponding set of 85 non-spin-off firms matched with the spin-off sample. The statistics for all the three data sets indicate that 75 percent of the abnormal returns were positive while the matched sample of non-spin-offs had just 39 percent positive price changes. This indicates that there is a high probability of stock price increases with spin-off decision compared to the portfolio of firms that were not undergoing spin-off event.

The mean of the spin-off abnormal returns is 21 percent compared to 4 percent for the non-spin-off sample. The standard deviation is quite close across the firms, which seems to suggest that these companies have similar risk patterns probably because spin-off parents are well established firms with long experience, with larger capitalization, which would lead to lower price volatility. The range between the minimum and the maximum for the spin-off samples is more than five times than that for the non-spin-off sample. This disparity is explainable as being caused by the spin-off effect on the measured variable around the time of announcement. There is no spin-off impact on the non-spin-off companies: implicitly, spin-off firms must have greater variability. The high Jarque-Bera test value in both samples indicates normality of the distribution of both the samples selected. 


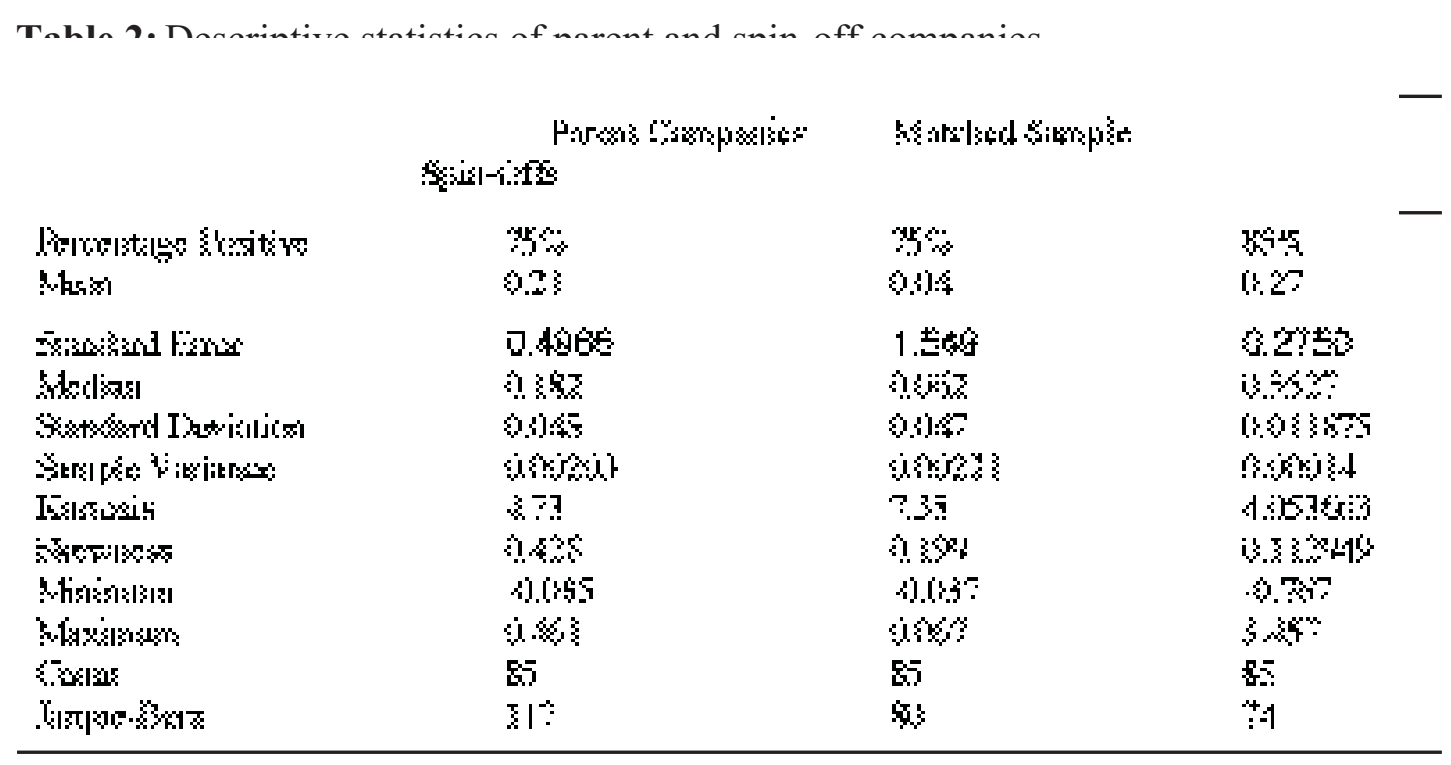

These statistics indicate significant positive abnormal returns of 8 percent higher than that of the parent companies. If median is a more reliable statistics given the distribution is not normal, the difference is 17 percent. By presenting these average abnormal returns values, we can see that there is a better performance in terms of wealth generation for the spun-off companies as compared to the parent companies. The skewness value shows more of the spin-off companies have abnormal returns more than 27 percent. This validates there are actual returns from the spin-off phenomenon for the spin-off companies. The range between the minimum and the maximum abnormal returns is more than seven times, indicative of again a non-normal distribution.

From the statistics, it can be deduced that, in Bursa Malaysia which is an emerging market, there has been wealth gains from Spin-offs. In addition, wealth garnered from the spin-off companies are more certain and greater in absolute terms than that of the parent companies in general.

\section{B: $\quad$ Spin-off announcement and ex-date effects}

In Table 3 the reader will find the test statistics on the CARs for selected windows. The first window of -50 to -2 is the pre-event period; the on-event period is -1 to 0 ; and the post-event period is for the post-event period. The CARs in the post-event period are expected to be not significant in an efficient capital market as all the information effect is absorbed either on the date of announcement $(\mathrm{t}=0)$ or in the days prior to the announcements. The abnormal returns, which are usually given for each day, are reported as means over the test window: a table going back -50 to +50 days will be too lengthy.

As is evident, the CARs for the parent firms amount to 22.7 percent $(0.227)$ on the on-event period. The size of the price effect is very large compared to means of under 7 percent reported in other studies in developed markets. The CARs for the on-event and pre-event windows are significant as well. The absence 
Table 3: Risk-adjusted abnormal returns surrounding spin-off announcements

\begin{tabular}{|c|c|c|c|c|}
\hline & \multicolumn{2}{|c|}{ A A } & \multicolumn{2}{|c|}{ 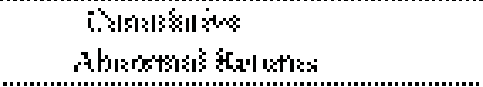 } \\
\hline & "र्या: & & 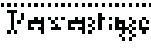 & \\
\hline 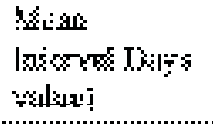 & $(i \cdot v \times \mid 13 c)$ & Xertilim & Fexitim & (i. \\
\hline 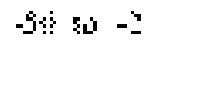 & $\begin{array}{c}(! .945 \\
(1.5 .51)^{*}\end{array}$ & $\lfloor. .5 . . \downarrow$ & $\because x$ & $\begin{array}{c}1.1^{\mathrm{m}}: 6 \\
(2.3 .3 \times 3)^{*}\end{array}$ \\
\hline$-1 \Leftrightarrow n \Leftrightarrow$ & $\begin{array}{c}3.905 \\
(1.93 .5)^{8}\end{array}$ & 3.99 .5 & 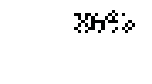 & 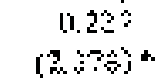 \\
\hline 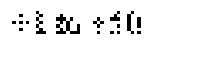 & $\begin{array}{l}4.5 \leq 3 \\
\{6.589\}\end{array}$ & ป. $\{x=2$ & mas & 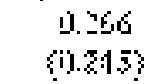 \\
\hline
\end{tabular}

Signiticant at U.I (*), U.US (**) and U.U1 $\left(^{* * *}\right)$ levels.

of significant post-event CAR is consistent with the tested market's known Famaefficiency, so it is as expected. Overall, these results appear to suggest that the shareholders of parent firms spinning new firms had significant increases in their firm values. This result is consistent with the literature and the theories about focused businesses as well as removal of hurdle rates constraints on subsidiaries increasing value in a focused business environment. Besides, there is less agency problem of the parent firm with a substantial portion of the parent being taken off from the current management: the agency theory predicts a positive price effect.

The two figures 1 and 2 are plots of the CARs from the risk-adjusted and market adjusted returns. Both show significant spikes in the returns in the period prior to the announcements. In Figure 1, the post-event trend, though it appears as large, is not statistically significant. In Figure 2, the trend is more marked. However, it is to be noted that the market adjustment method is likely to be biased

Figure 1: Plot of risk-adjusted CARs over -100 through +50 for the parent companies

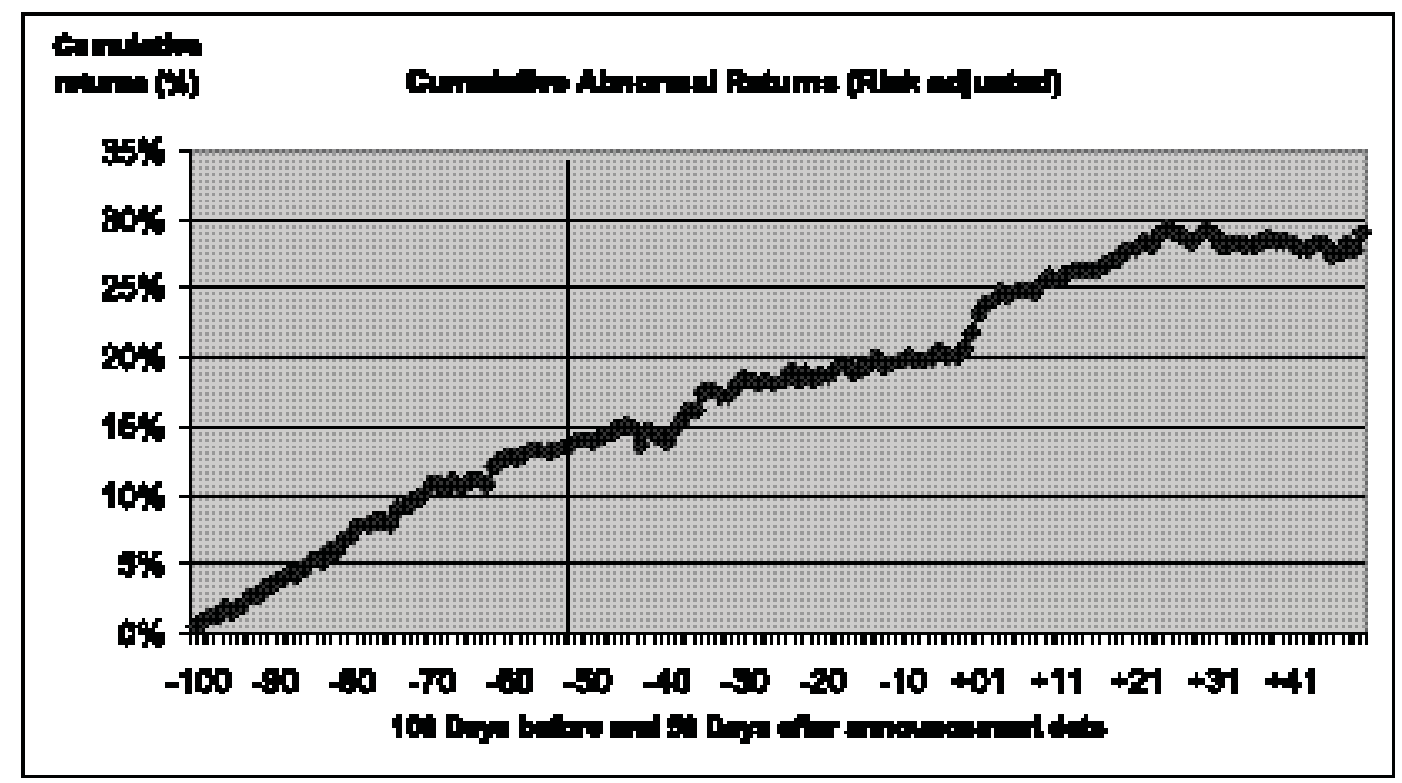


Figure 2: Plot of market adjusted CARs -100 to +50 days for the parent companies

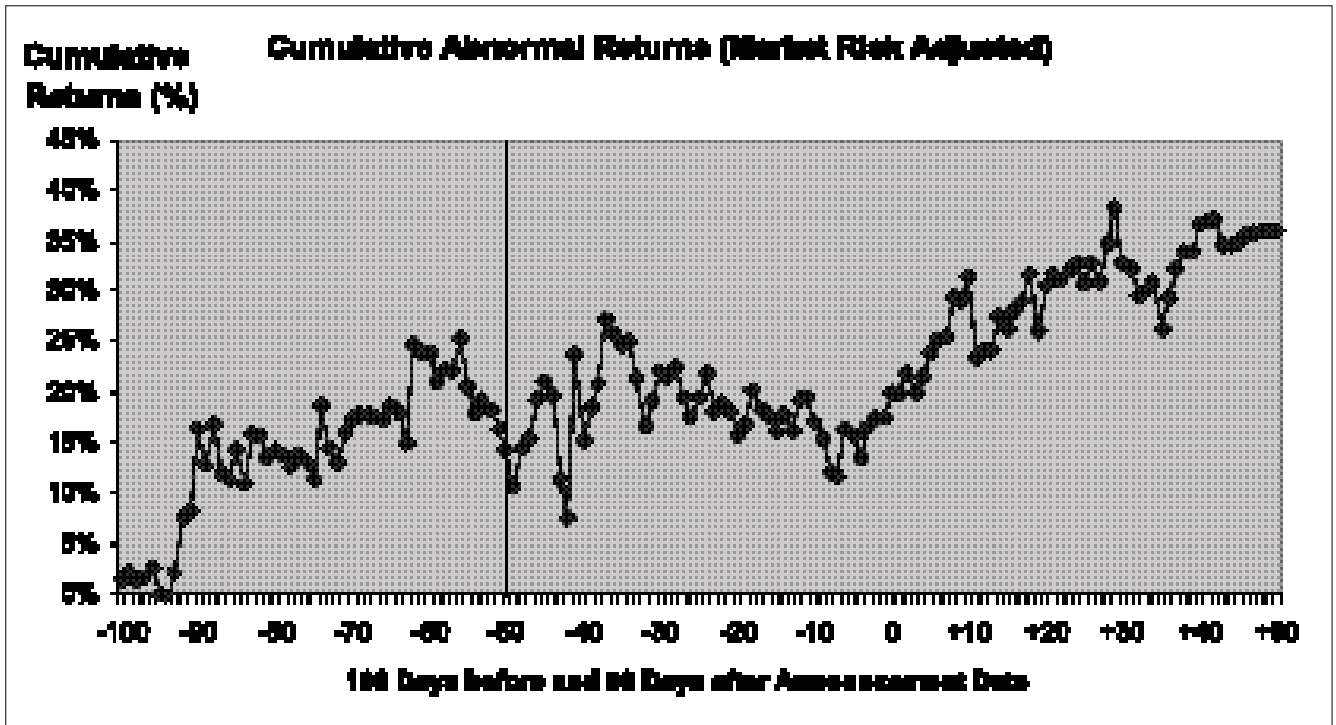

Figure 3: Plot of CARs using control sample-adjustment for the parent companies

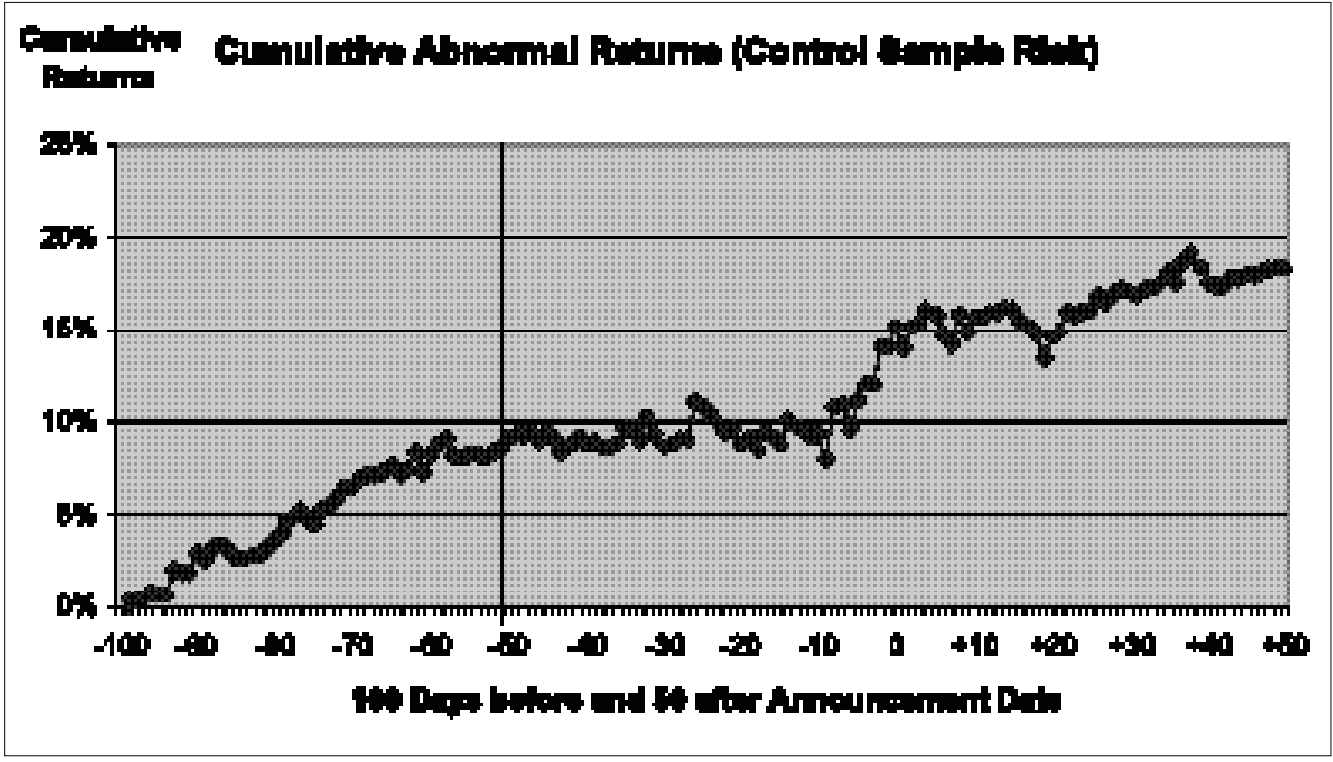

since the spin-off parent firms have betas lot different from 1, hence, the lack of risk-adjustment would make this measure introduce some bias in the plotted graph. The plots appear to suggest that the on-event and pre-event trends are more pronounced, and are likely to be significant.

The plot in Figure 3 is by taking the difference between the gross returns fo the spin-off parent firm returns from and the control sample of matched nonspin-off firms. In a sense, the use of this method distinguishes this study from others. As mentioned in the methodology section, we deem this method to be more reliable for studying the event effect of spin-off in emerging markets where there are many factors that could not be controlled, and empirical evidence shows that the price behavior have peculiar impacts from regulatory regime in place as 
well as the transient effects from portfolio flows into this market. The shape of the plot suggests that the on-event impact between day -10 and day +1 is very pronounced. It is more pronounced than the impact in the pre-event period from -95 days to -11 days. The post-event impact is much more muted, very unlikely to be significant. Summarizing the behavior of the event impact on share prices of parent firms, it is evident that there is significant shareholder value increase in the parent firm in the period up to the event date.

Now, the results on the spin-off firms are presented in the ensuing discussion.

Figure 4: Plot of market adjusted CAR for the spin-off companies

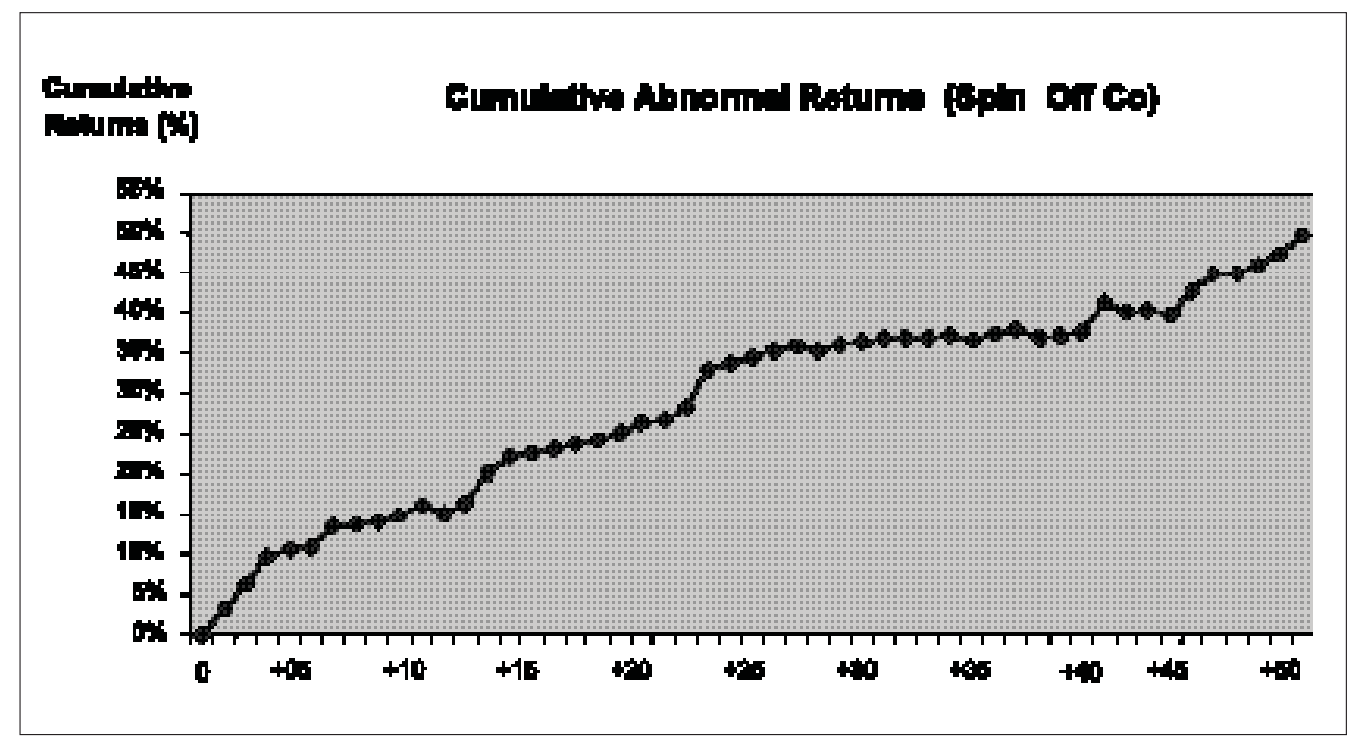

This plot refers to the increase in value of the separated firm from the date of listing and trading of the spin-off firms. A priori, it can be argued that the shareholders of the spin-off companies are the same as the shareholders of the parent company at the time of listing of the spin-off. Spin-off shares are given in proportion to the existing share owners of the parent firm: unlike in the developed countries, spin-off in Malaysia is a closed shop affair as no members of the public are given any shares in the new firm. Hence, any observed increase in the share prices of spin-off firm after the listing day arises from the market's re-valuation of the spin-off firm by the subsequent purchasers of the shares after listing, as is consistent with their valuation they place on this new firm coming to the public for the first time. Thus, as in Hypothesis 1, any increase in the value of the spinoff is a transfer of wealth from the event to the shareholders. The trend clearly evident in this plot suggests a 50 percent increase in value to the original shareholders' value in the spin-off firm.

The market reacts to the spin-off announcement for both entities. However, the reaction is at different days during the analysis period. This phenomenon is 
consistent with observed pattern in a study of stock price reaction to share repurchases: Lim and Obiyathulla (2002). However, in a study of the impact of accounting earnings disclosure on stock prices in Malaysia these findings can be explained by the familiarity of the market participants towards spin-offs. In any case, this can be interpreted as the revaluation by investors buying into the firm that was closed to them before as being valued higher in the hands of the public. This is not evidence of market inefficiency as some would suggest. We estimated this new finding as being relevant to the study of spin-offs as previous studies only examined the announcement day impact. Part of the reason for this price increase is also the leakage of information that comes from post-listing news of the worth of the spin-off companies from the analysts as well as the news of the court hearings that would be completing just about the time of the listing.

Following the reason often advanced for a spin-off that the parent company wants to reduce the diversity of its business operations, the parent spins off the subsidiary because its core business is very different from that of the rest of the parent's operations. Focus may be a determinant of spin-off. In most efficient economies, resources flow to where they are best utilized for the benefit of society. Therefore, since material resources are generally scarce and inequalities exist in entrepreneurial skills, some members of society will own means of production while others will not, even though they may lose their focus to do so.

Owners of corporate organizations and their agents should understand that they are using these resources to produce goods and services to improve the quality of life of society. Corporate organizations are to use these resources efficiently for the benefit of the society. To the consumer, efficiency means the product is of good quality, affordable and has the ability to provide the services it was designed for. To move into a responsible position to carry out such business philosophy, a company must first be established. Hence, the age of a company is offered here in this study as a predictor to such a motive. Generally, the older a company, the more establish she becomes.

The companies have been announcing spin-off for the purposes of consolidating efforts on core operations. The Genting Group's spin-off of Resort World focuses on the casino operations. The Tan Chong Group's spinning-off its spareparts division is another example. Such spin-offs may benefit the parent company in three primary ways. The parent company may be better able to concentrate on its managerial, personnel, distributional and production resources in one or a small number of operational areas. Spinning off areas of operations unrelated to the parent company's core business will decrease diversification. This decrease will raise the firm's volatility of earnings and subsequently, increase the value of the leveraged firm. Spinning off the company into multiple operating units will enable investors to purchase just those operations which will provide a proper fit into their own portfolios. This "clientele" effect may serve to increase the total value of the company. 
During the 1990s, some of the largest public companies spun-off major chunks of their assets in an effort to increase their share values. Reversing their efforts towards conglomerate formation begun in the 1980s and continued into the early 1990s, Berjaya Group Bhd spun-off three distinct companies; Berjaya Capital; Cosway Corporation; and Nam Fatt Corporation. The conglomerate Sunway Holding Incorporation separated Sunway Building Technology when it spun-off this division. YTL Corporation, in a more conventional manner, spunoff its YTL Cement. Telekom Malaysia spun-off its subsidiary Celcom after acquiring the unit two years earlier. From the above mentioned cases involving large companies, it can be seen that Market Capitalization can be a factor to spinoff.

Under certain circumstances, spin-off can reduce the overall tax burden of a corporation. That is to say that the combined taxes of the parent and spin-off company being reduced. This is because the spin-off can derive tax benefit from unused capital allowances and investment tax credits. Spin-off activity can prevent the permanent loss of tax credits that would otherwise accrue to companies with negative incomes. Companies losing money frequently cannot benefit from tax credits. Spinning-off such firms to join as a profit making firms can create value by preventing the permanent loss of such credits. There are situations that exist where after the spin-off, it can be more highly geared, thus reducing overall tax burden. However, tax gains cannot be realized more than in the case of mergers and acquisitions as there is no group relief for tax i.e. each entity is taxed separately.

There can still be a number of other factors for the spin-off activity. Spin-off increases shareholders wealth, presumably at the expense of the bondholders wealth though no evidence can be forwarded as of yet. The argument is that by taking a portion of the assets fo the parent, the bondholders to the parent has now lost collateral, and hence the risk of the debt increases, thus the bond value goes down. Consequence of that is the increase in shareholder value. These extemporaneous factors are not included in the regression model in view of their ambiguity as outlined in previous studies: see fro example Hite and Owers (1983) and Schipper and Smith (1983).

\section{C: $\quad$ Findings from regression analysis}

The summary statistics on the variables are given in Table 4 . The median for the variables of Focus and Tax were 0 because these are dummy figures of 1 and 0 . Following the same note, minimum and maximum figures of 0 and 1 are used for Focus and Tax respectively. As for the Market Capitalization and Age, the median is not far from the mean indicating that the related values are quite close in absolute amounts. Here, the large absolute values for Market Capitalization were in common logarithm for accuracy and simplicity reasons. Except for the Age variable, where the Kurtosis value is very large and the Jarque-Bera test 
Table 4: Descriptive statistics of focus, tax, market capitalization and age

\begin{tabular}{|c|c|c|c|c|}
\hline & Esa: & lins & $\begin{array}{c}\text { MAtst } \\
\text { mitran int }\end{array}$ & $\therefore$ \\
\hline Bxous & !.t. & 0.3463 & s. $\$ \$$ & $=9 \pm 430$ \\
\hline 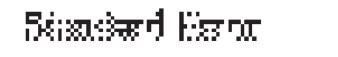 & $4.84+11 ?$ & i'. 1 :Py & $\because 9 i j 5 \%$ & 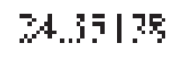 \\
\hline Srotikn & $\therefore$ & $\therefore$ & 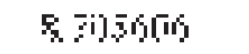 & 2.39350 \\
\hline 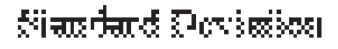 & {$[15952$} & 44248 & {$[.94013$} & $0 ., 3 \times 2,53$ \\
\hline stapple risizir & $0.218+21$ & {$[1] 38$} & $\theta=5 x$ & [. $12 \% \%$ \\
\hline Kuthes & 78008 & 1.7371\% & $-1,20+19 t$ & ?oshts \\
\hline 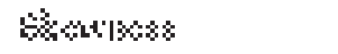 & 1. $\$ 76131$ & $635: 5 \%$ & $A .2+j \div$ & 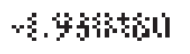 \\
\hline 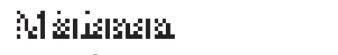 & $\phi$ & $\dot{t}$ & $2 \mathrm{~J} 122 \mathrm{~g}$ & 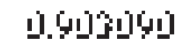 \\
\hline 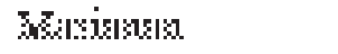 & I & $\mathrm{s}$ & 75748 & 258155 \\
\hline Axpla Iff-a & 4 & 38 & F던 & 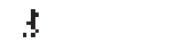 \\
\hline Gostas & 35 & 85 & A5 & $\mathrm{n}$ \\
\hline
\end{tabular}

Table 5: Statistics on variables regressed against the CAR of parent companies

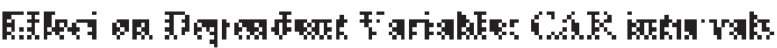

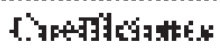

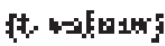

\begin{tabular}{|c|c|c|c|c|c|}
\hline .7nter ral & $\therefore$ is ij & $\phi$ & 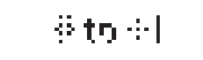 & $x 1$ th & 5 inds \\
\hline \multicolumn{6}{|l|}{ 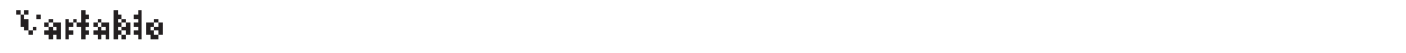 } \\
\hline$\beta_{\text {ijs: }}$ & 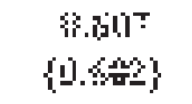 & $\begin{array}{r}6455 \\
\{0.8>9\}\end{array}$ & $\begin{array}{l}0.345 \\
0.495\end{array}$ & $\begin{array}{l}\$ 560 \\
\{0 .\langle 0 \%\}\end{array}$ & $\begin{array}{l}0.116 \\
0.4 \times\end{array}$ \\
\hline Tlis & $\begin{aligned} 0.860 \\
0.711)\end{aligned}$ & $\begin{array}{r}-0.46 \% \\
-0.65\end{array}$ & $\begin{array}{r}1.64 \% \\
10.03 \%\end{array}$ & $\begin{array}{l}0.1 \% \\
6 \leftrightarrow \%, \mathrm{y}\end{array}$ & $\begin{array}{l}0.82 \\
0.019\end{array}$ \\
\hline 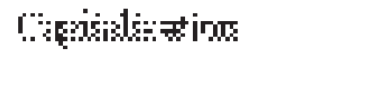 & 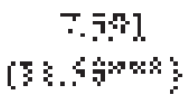 & 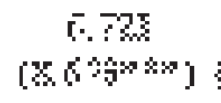 & $\begin{array}{c}1.30 \\
160^{\infty \times m}\end{array}$ & 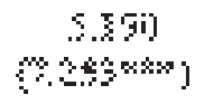 & 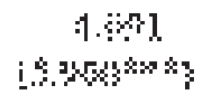 \\
\hline 48 & $\begin{array}{l}-3.345 \\
\text { (ii)s:4 }\end{array}$ & $\begin{array}{c}2.10 ! \\
4-154^{\infty} \times !\end{array}$ & $\begin{array}{l}-3.84 ! \\
0.94 \div !\end{array}$ & $\begin{array}{r}-1 . \% 4 \\
\gamma(1.97 \% !\end{array}$ & $\begin{array}{r}-11.156 \\
4 \mathrm{iij} .259\end{array}$ \\
\hline \multicolumn{6}{|l|}{ inged } \\
\hline 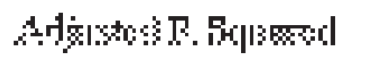 & (1) & {$[.7$} & $i . \%$ & $4.5 \%$ & 6.70. \\
\hline 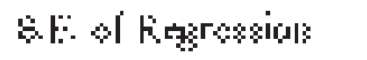 & $22 x$ & $26+1$ & $1 . .51$ & 1. 190 & D. I fel \\
\hline 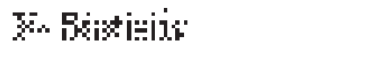 & $78 . \$ \overline{7}$ & $75.1 \%$ & 13.713 & $\leq .7 \%$ & 8.54 \\
\hline 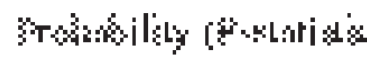 & $\theta \sin$ & 1. Fiptos & $1 . \$ \beta^{+}+4$ & (1) & $A \phi \phi^{+}$ \\
\hline
\end{tabular}

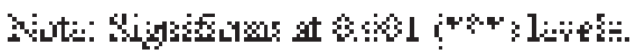


value is small, the statistics for all other variables show normal distribution of the data set. The Kurtosis value is closed to 3 and the Jarque-Bera test records a high value, showing normality as the result.

The statistics in Table 5 reveals that for the parent firms, the regression model is significant with an F-ratio of 5.549 and above. The R-squared values are very high suggesting a good amount of explanatory power of these variables in the model. The first variable, Focus of business, is not significant and the sign is as predicted. The second variable behaves the same way with the correct sign, except for the test window of one day, $t=0$. The two other variables size and age of company are significant. The bigger the size of the parent the bigger is the price effect; the age is negatively correlated as older firms being larger would have less risk, and hence the returns would be less. Prior studies in the matured markets in Europe and the U.S. had similar results. Thus, we have only two of the variables affecting significantly the pricing behavior in spin-off parent firms in this emerging market place.

The spin-off firms may behave differently, so the model was applied to the spin-off firms: see the statistics in Table 6.

From the tabulation of the regression results in Tables 6, it can be deduced that the regression methodology is valid. The coefficient of determination is pretty high as the adjusted R-squared of average 59.6-82.7 percent is much higher than in the cases of parent firms. The F-statistic of 11.362 and higher are also found to be significant as the probability of this value is 0.00 and lower Thus, the regression model is valid and there is no risk in rejecting the null hypothesis of no relationship with the independent determinants.

On the significance of the independent variables, Tax and Focus are not statistically significant although, as with the parent firms, the signs are in the right direction. The coefficients of Market Capitalization and Age (except in one window) are also not significant: the signs are also perverse for the Age factor. Unlike prior studies by Hite and Owers (1983), Veld and Merkoulova (2003), focus factor is not proven to be significantly relevant. The same goes to Tax factor, it does not appear as a predictor even though it is well taken as a determinant in prior studies in the US by Hite and Owers (1983), Copeland, Lemgruber and Mayers (1987). This is in line with the argument that emerging has no specific tax regulations on Spin-off and does not practice group tax loss relief, thus the impact ought to be not significant. The regulations that were used for guidance for spin-off are confined to listed companies listing their subsidiaries and RPGT concerns for transferor transferring shares in land-based companies. Thus, in the absence of a generous tax relief as in the matured markets, the tax factor in the tested market is perhaps unimportant as suggested by the test result (except for the sign).

The higher the Market Capitalization, the higher is the CAR. This result is similar to that in the US: Schipper and Smith (1983); Hite and Owers (1983); 
Table 6: Statistics on variables regressed against the CAR of parent companies

\begin{tabular}{|c|c|c|c|c|c|}
\hline & \multicolumn{5}{|c|}{ 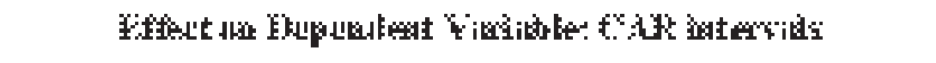 } \\
\hline & \multicolumn{4}{|c|}{ 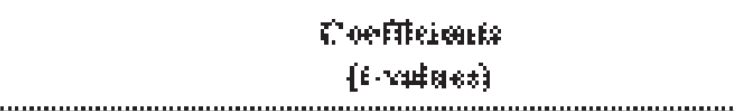 } & \multirow[b]{2}{*}{ 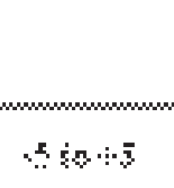 } \\
\hline & . 1 in & 6 & i] 8 & $A \sin +2$ & \\
\hline 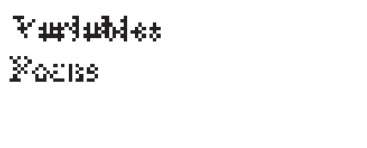 & $\begin{array}{l}0.692 \\
6787\end{array}$ & 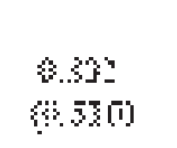 & $\begin{array}{c}0.3 \% 2 \\
40.52\end{array}$ & 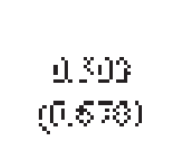 & $\begin{array}{l}0.83 \\
0.8 \% !\end{array}$ \\
\hline Tik & $\begin{array}{c}\leftrightarrow 2 \% \\
\{64\}\end{array}$ & $\begin{array}{l}9600 \\
6986\end{array}$ & $\begin{array}{l}\text { क. } \\
4 B 9\end{array}$ & $\begin{array}{l}0.1 \% 3 \\
0.2 \pm 1 ;\end{array}$ & $\begin{array}{r}0.1 ; 5 \\
6.213\end{array}$ \\
\hline Gibianil & $\begin{array}{l}0.145 \\
64553\end{array}$ & $\begin{array}{l}0.268 \\
6.09\end{array}$ & $\begin{array}{r}0.1 \% \\
\{0 \ldots+3\end{array}$ & $\begin{array}{l}0.81 \% \\
40.191)\end{array}$ & $\begin{array}{c}\text { olts } \\
605 \%\end{array}$ \\
\hline$A \beta$ & $\begin{array}{c}1.9 \% \\
19 \%\end{array}$ & 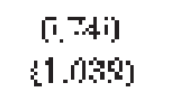 & $\begin{array}{r}0.531 \\
0.826\end{array}$ & $\begin{array}{c}\text { i]. } 12 \% \\
\text { is.3.39) }\end{array}$ & $\begin{array}{r}450 \\
\text { ans? }\end{array}$ \\
\hline \multicolumn{6}{|l|}{ stotefis } \\
\hline 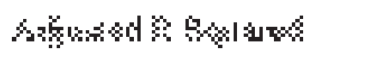 & 0.69 & 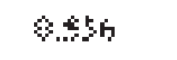 & $A B$ & 0.69 & $0.67,8$ \\
\hline 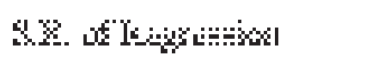 & B. & $2.61+$ & stro & 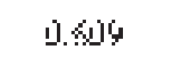 & {$[1 . \otimes \underline{\mathrm{I}}$} \\
\hline Ystal istm & $1 \% \$ 00$ & $1 \% .90$ & $3 \% \times \%$ & $B . A S I$ & 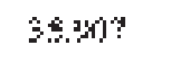 \\
\hline 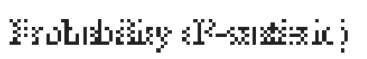 & का! & $\operatorname{s!n}[!+\infty *$ & $\mathrm{J} . \mathrm{s} \| \mathbf{I} * * *$ & 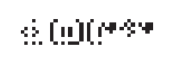 & $0 \%$ \\
\hline
\end{tabular}

Sipaitic

Copeland, Lemgruber and Mayer (1987); Kudla and McInish (1988); and Krishnaswami and Subramaniam (1999). Generally, market capitalization grows with the age of a company in that the longer is the firm in existence, hence, frequently more established is the company with market capitalization increasing. If this case is prevailing in this study, then it will give rise to high correlation between the variables, capitalization and age. In order to ensure that the regression analysis is not affected by multicollinearity problem caused by these two variables, a different run of the regression was done with the age variable, and then the capitalization variable dropped. However, the results of the second and third regressions show no differences with the initial regression output in Table 5 and 6. Therefore, the initial regression results where the four independent variables were reported.

The Market Capitalization factor can be supported by Freeman's (1987) argument that larger firms provide a greater variety of information than smaller firms and larger firms have greater exposure in the media. Large firms are more 
likely to have additional information reported in the form of interim financial reports, analyst forecasts, industry forecasts, management forecasts and even litigation. Another explanation is that trading by informed investors reveals private information. Atiase (1985) argued that the partial revelation of private information by informed investors reduces the potential for profits in small firms to a greater extent because private information is more noticeable in thinly traded stocks. This factor limits the potential to exploit the knowledge of a misinformation in a small firm, and is an added incentive to undertake research on large firms rather than small firms. Institutional investors are likely to concentrate on large firms due to liquidity constraints. For example, institutions cannot hold a large percentage of stock of a small firm and expect to be able to sell the stock immediately without price discounts. Further, because institutions are a major source of demand for information, financial analysts may concentrate their search activities on larger firms.

\section{Conclusions}

This study was motivated to contribute by way of newer method of analysis restricted to the study of spin-off in emerging markets. The market chosen is ranked as among the top-20, although it is in an emerging economy. We analyzed a sample of 85 parent companies and their spin-off firms using the announcement information over a recent 23 years. The average CAR over the -100-day event window was more than 20 percent for the parent companies and more than 25 percent for the spun-off companies. The trend of the abnormal returns charted in the study shows that the wealth increase due to spin-off is some 5-6 times higher than is the case in studies in developed economies. The first two hypotheses about the wealth effect accruing to the parent shareholders and the information effect at the time of announcement on the share prices of parent companies have been shown to hold significantly.

Tax, Age, Market Capitalization and Focus factors were considered as possible determinants of spin-off performance, as is suggested in the literature. The study reveals that Market Capitalization and Age factors are significant to the market price variation particularly for the parent firms, not so for the spin-off firms. These findings are, in our opinion, robust as we applied a matched-sample procedure to control for unknown factors in the emerging market. In fact the results from the matched sample procedure appear to provide a robust set of results. More studies of this kind are needed to generalize the findings to other emerging markets as being much more pronounced than in the developed capital markets studied so far.

Acknowledgment: This is one of three papers at the FMA-Asian Finance Association $200517^{\text {th }}$ Conference that won best prize award as selected by the 
editors of the Journal. The authors thank the Editorial office for the revision of the paper as per the review comments. For errors, the authors take full responsibility.

Author statement: Yoon Chung-yin is a partner of the accounting firm and the co-author holds a chair in finance at the named university. Yoon presented the paper, and won the best paper prize for this paper at a conference. Ariff holds the Renong endowed chair as a visiting professor at the University Putra Malaysia. The authors wish to thank Taufiq Hassan Chowdury at the UPM for the invaluable assistance in the research process.

\section{References}

Ariff M., and Johnson, L. W. (1990). "Securities Markets and Stock Pricing Evidence in a Developing Equity Market in Asia" Longman Professional Books, London, Singapore and Sydney.

Annuar, M. N., Ariff M and Shamsher M., (1994) 'Is Kuala Lumpur's Emerging Share Market Efficient?" Journal of International Financial Markets, Institutions and Money (4) 2 89-100

Barry C B, Peavy J W, and Rodriguez M (1997) "Performance Characteristic of Emerging Capital Markets" Emerging Markets Quarterly (Spring) 41-48.

Brown, S. J., \& Warner, J. B., (1985). "Using Stock Returns The Case of Event Studies" The Journal of Financial Economics 14: 3-31.

Copeland T, Lemgruber, E. F., and Mayers, D., (1987) "Corporate Spin-Offs: Multiple Announcement and Ex-Date Abnormal Performance" Modern Finance and Industrial Economics, Chapter 7 T E Copeland, ed. New York: Basil Blackwell Press.

Cusatis P.J., Miles. J. A., and Woolridge, J. R., (1993). "Restructuring through spin-offs" The Journal of Finance Economics 33: 293-311.

Fama, Eugene (1980). "Agency Problems and the Theory of the Firm," Journal of Political Economy 88: 288-307

Fama, E., Fisher, J., \& Roll, R., (1969). "The Adjustment of Stock Prices to New Information" International Economic Review 1-21.

Fama (1970) "Efficient Capital Markets: A Review of Theory and Empirical Work" The Journal of Finance 383-417

Government of Malaysia "The Companies Act of Malaysia 1965” Government Printers

Government of Malaysia "The Real Property Gains Tax Act 1976” Government Printers

Galai, D., and Masulis, R., (1976). "The Option Pricing Model and the Risk Factor of Stock" Journal of Financial Economics 3: 53-82. 
Habib, M. A., Johnsen, D. B., and Naik, N. Y., (1997) "Spin-offs and Information" Working Paper, London Business School.

Hite, G. L., and Owers, J. E., (1983). "Security Price Reactions around Corporate Spin-Off Announcement" Journal of Financial Economics 12: 409-436.

Jensen M., and Meckling, W., (1976). "Theory of the Firm: Managerial Behavior, Agency Costs and Ownership Structure" Journal of Financial Economics 3: 305-360.

Johnson and Klein, J., (1996). "The effects of Spin-Offs on Corporate Investment and Performance" The Journal of Financial Research 19(2): 293-307.

John, T. A., (1993). "Optimality of Spin-Off and Allocation of Debt" Journal of Financial Quantitative Analysis 28: 139-160.

Schipper, K., and Abbie Smith (1983). "Effects of Recontracting on Shareholder Wealth - The Case of Voluntary Spin-offs" Journal of Financial Economics 12: 437-467.

Klein A (1986). "The Timing and Substance of Divestiture Announcements: Individual, simultaneous and Cumulative Effects" The Journal of Finance 41 (July): 685-697

Krishnaswami, S., and Subramaniam, M., (1999). "Information Asymmetry, Valuation, and the Corporate Spin-offs Decision" Journal of Financial Economics 53: 73-112.

Kuala Lumpur Stock Exchange "Companies Handbook" Volume 1-3.

Kudla, R. J., and McInish, T. H., (1988). "Divergence of Opinion and Corporate Spin-offs" Quarterly Review of Economics and Business 28(2): 20-29.

Lim, E. H., and Obiyathulla, I. B., (2002). "Price Reaction to Stock Repurchase; Evidence from the KLSE" Working Paper, International Islamic University Malaysia.

Miller, M., (1976). "Debt and Taxes" The Journal of Finance 31: 279-308.

Miles, M., and Rosenfeld, J., (1983). "The Effect of Voluntary Spin-Off Announcements on Shareholder Wealth" The Journal of Finance 38(5): 1597-1606.

Schipper, K., and Smith, A., (1983). "Effects of Re-contracting on Shareholder Wealth: The Case of Voluntary Spin-offs" Journal of Financial Economics 12: $437-467$.

Seward, J., and Walsh, J., (1996). "The Governance and Control of Voluntary Corporate Spin-offs" Strategic Management Journal 17: 25-39.

Sharpe, W. F., (1963). "Capital Asset Prices: A Theory of Market Equilibrium under Condition of Risks" The Journal of Finance 3: 309-327.

Vijh, A. M., (1994). “The Spin-off and Merger Ex-Date Effects" The Journal of Finance 19(2): 581-609. 


\begin{abstract}
APPENDIX A
Key requirements of Spin-off of a Listed Company and Real Property Company, Malaysia
\end{abstract}

\title{
1. Profitability of Parent
}

The pretax profits, profits after tax and net tangible assets of the subsidiary or associated company to be listed should not account for more than 35 percent respectively of the consolidated pretax profits, profits after tax and net tangible assets of the Group in respect of the past five years for a Main Board listing or three years for a Second Board listing. In addition, if the consolidated pretax profit of the holding company is reduced by more than 15 percent in the financial year following that in which the subsidiary or associated company is listed, the parent company, consequently upon listing of its subsidiary or associated company, will have to make good the shortfall within six months in the following year, failing which the parent company will be suspended;

\section{Capital Issuing Committee (CIC)}

The parent company excluding the subsidiary or associated company to be listed and existing listed subsidiary or associated companies should on its own meet CIC's requirements for listing as if it were a new company seeking listing.

\section{Separate Business}

The applicant subsidiary or associated company should be involved in a particular business of its own with profits able to meet CIC's criteria for listing with respect to track record and future prospects;

\section{No Intra-Group Competition}

The relationship. between the subsidiary or associated company seeking listing and the other companies within the group, including the parent company, should not give rise to intra-group competition or conflict of interest situation.

\section{Independence}

The subsidiary or associated company to be listed should demonstrate that it is not overly dependent on the other companies within the Group, including the parent company, in terms of its operations, including purchases and sales of goods, management policies and finance;

\section{Real Property Companies}

Prior to 1997, Real Property Company (RPC) shares are deemed to be acquired on the date the relevant company becomes a real property company 
or on the date of acquisition of the RPC shares, whichever is later. If the relevant company acquires additional real property or shares or both equivalent to 50 percent or more than those which it already owns, the date of acquisition of the RPC shares will shift forward to the date of acquisition of the additional real property or shares. After 1997, the deemed date of acquisition of RPC shares will no longer shift forward on purchase of additional real property or shares. If at that date of acquisition of shares, the relevant company was already a RPC, the deemed acquisition price will be either the consideration paid together with the incidental costs for the RPC shares or the deemed market value of the RPC shares in the event that the shares were not acquired at arms length. The acquisition price of bonus RPC shares will be zero since no consideration has been paid for the shares. However, the acquisition price of shares acquired through right issues will be the consideration paid for the rights issue. The new rule after 1997 may be unfair to disposers of RPC shares if the appreciation in value of the shares is not due solely to appreciation in value of the underlying property but to the retention of profits in the RPC and appreciation of other properties purchased subsequent to the date of acquisition of the RPC shares. 


\section{APPENDIX B \\ Key requirements of Tax-free Spin-off, United States}

\section{Controlled Corporation}

To qualify as a tax-free spin-off, the distributing corporation must distribute the stock of a controlled corporation preexisting or newly created to its shareholders. Provided the companies meet the active business requirement (see requirement 3 below), the distributing corporation has significant latitude in the assets it transfers to the controlled corporation. For purposes of this requirement, control is defined as owning at least 80 percent of the voting power and at least 80 percent of the shares of each class of nonvoting stock.

\section{Securities Distribution}

The distributing corporation generally must distribute all its controlled corporation stock and securities immediately before the transaction. Revenue procedure 96-30, however, allows the distributing corporation to retain a limited amount of the stock or securities if the stock is widely held, the retention satisfies a significant business purpose, the controlled corporation officers and directors are officers and directors of the distribution corporation, the retained stock and securities are disposed of as soon as possible but no later than five years after the separation and the distributing corporation votes the retained stock in the same proportion as the stock distributed. In all cases, stock meeting the control definition must be distributed.

\section{Active Businesses}

Following the distribution, both the controlled and distributing corporations must be actively engaged in a trade or business with a five-year history. Regulations section 1.355-3(b) defines an active trade or business as one in which all the necessary steps or activities take place to earn a profit. An active business does not include ownership of investments such as stock or land or the leasing of real or personal property unless the corporation provides significant services related to the property.

4. Not a Distributing Device

Neither the distributing nor the controlled corporation can use the spin-off as a device for distributing earnings and profits. Because of its vagueness, this requirement usually is the most troublesome. The key issue is whether the spin-off is indistinguishable from an ordinary dividend. Regulations section $1.355-2$ (d) tries to help by listing factors that indicate when the spin-off (or other corporate division) is or is not a device for distributing 
earnings. A spin-off starts with one strike against it: The first device factor is "pro rata distribution," the very essence of a spin-off. Regulations section 1.355-2 (d)(5), however, discusses distributions that have no tax avoidance potential and thus may satisfy the device requirement even if one or more device factors are present. For example, a distribution ordinarily would not be a device if the distributing and controlled corporations have no accumulated earnings and profits.

\section{Business Purpose}

Regulations section 1.355-2(b) requires a spin-off to be "motivated, in whole or substantial part, by one or more corporate business purposes." The purposes must be "real and substantial" and "germane" to the distributing or controlled corporation's business or to the affiliated group of which the distributing corporation is a member. Neither reducing federal income taxes nor satisfying a shareholder purpose is a corporate business purpose. However, a distribution made primarily to achieve a corporate business that also achieves a shareholder purpose is not disqualified. A corporate business purpose also fails the test if it could be accomplished in a nontaxable transaction that is not "impractical or unduly expensive."

The subjectivity inherent in the above rules, as well as intense IRS scrutiny, has made the business purpose requirement one of the most difficult hurdles a company must overcome to ensure tax-free treatment. The revenue procedure 96-30 removes some of the subjectivity by discussing at length the qualifying criteria and the information companies must submit for advance rulings for each of nine business purposes that may qualify a spin-off for tax-free treatment.

\section{Continuity Of Interest}

Regulations section 1.355-2 (c) says that following the distribution of the controlled corporation's stock, the distributing corporation shareholders must maintain continuity of interest in both companies. Revenue procedure 9630 further says this requirement generally is met if one or more persons who directly own the distributing corporation before the distribution also own 50 percent or more of the stock in each of the modified companies after the separation. 


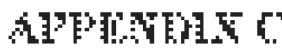

Second y

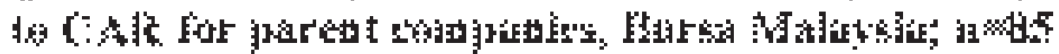

\begin{tabular}{|c|c|c|c|c|c|}
\hline \multicolumn{6}{|c|}{ 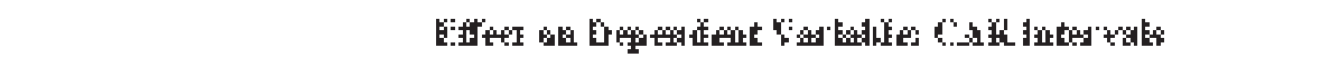 } \\
\hline \multirow[b]{2}{*}{ Hinted $\div *$ a } & \multicolumn{4}{|c|}{ 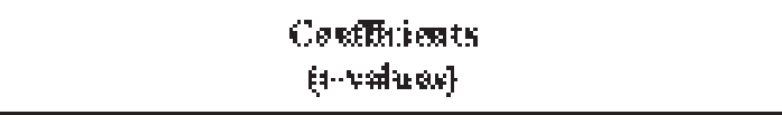 } & \multirow[b]{2}{*}{$-510+4$} \\
\hline & -1804 & I & $\$ t:-1$ & $-1 t=\because 1$ & \\
\hline \multicolumn{6}{|l|}{ 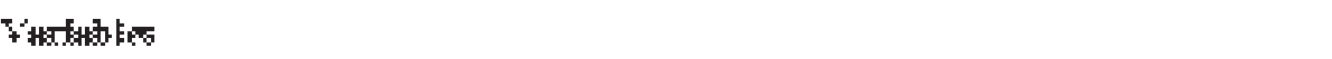 } \\
\hline Pịकs: & $\begin{array}{l}\alpha \% 4 \\
\cdots r_{E} \mid y\end{array}$ & $\begin{array}{l}6.80 s \\
6.4 \% \pi\end{array}$ & $\begin{array}{r}0056 \\
185301\end{array}$ & $\begin{array}{r}491 \% \\
\text { \&.i\%? }\end{array}$ & $\begin{array}{l}\operatorname{css} \\
i 0.40 \%\end{array}$ \\
\hline$\nabla=$ & 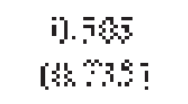 & $\begin{array}{c}44 \% \\
4 \phi \$ \$ ?\end{array}$ & $\begin{array}{l}\square .8: 7 \\
\square \times 48\end{array}$ & 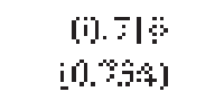 & $\begin{array}{r}872 \\
{[\$ 565}\end{array}$ \\
\hline Contingina & 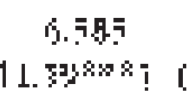 & $\begin{array}{c}4.47 \\
\left.4.4^{-6 m}\right)\end{array}$ & 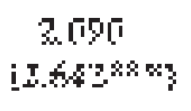 & $\begin{array}{c}5.400 \\
i \sin 609\end{array}$ & (15) \\
\hline \multicolumn{6}{|l|}{ thation } \\
\hline B. splantist & 1.64 & 0.75 & $0 . \otimes i$ & \$.717 & 695 \\
\hline 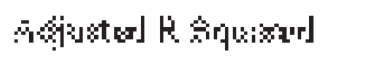 & $0 . \$ 31$ & SGI & li. ant. & $\sin$ & 9.461 \\
\hline 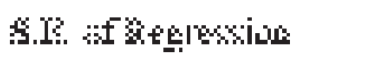 & 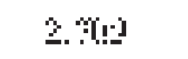 & 1. [1: & $2 .+6 \pm$ & $2 \times 1$ & G.ol \\
\hline Thentiv & 4721 & $12: 7$ & $74: 5$ & $E[., 8: 3$ & 32.57 \\
\hline 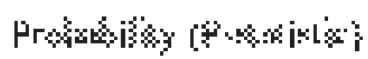 & $\sin ^{+}+$ & क.in & $4 . \$ 1 \%+4$ & क.ini & $0 . \$ \%$ \\
\hline
\end{tabular}

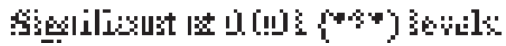




\section{APPWHA E}

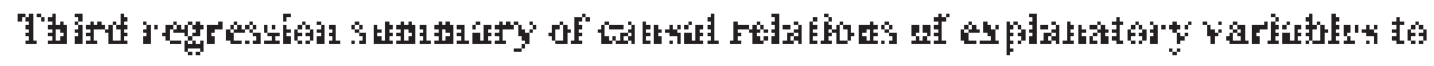

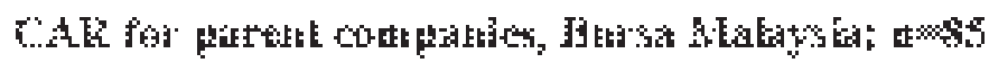

\begin{tabular}{|c|c|c|c|c|c|}
\hline \multicolumn{6}{|c|}{ 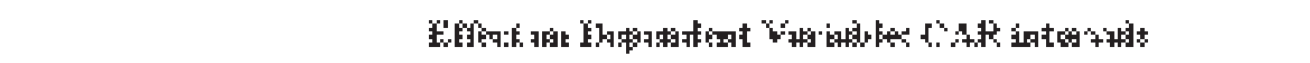 } \\
\hline \multirow[b]{2}{*}{ EAtarat } & \multicolumn{4}{|c|}{ 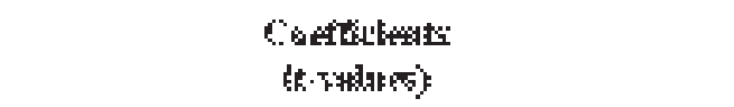 } & \multirow[b]{2}{*}{$5+5$} \\
\hline &. $\sin \theta$ & 0 & $\ominus \diamond+1$ & 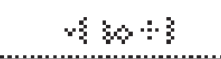 & \\
\hline 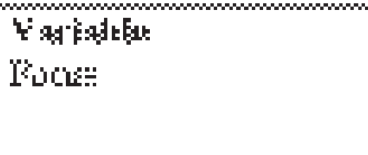 & $\begin{array}{l} \pm .: 16 \\
0.5 \%\end{array}$ & 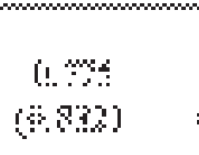 & 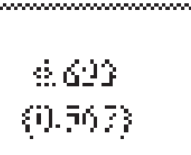 & $\begin{array}{l}0.83 \\
(1.653)\end{array}$ & $\begin{array}{l}483 \\
40.171\}\end{array}$ \\
\hline Yro & $\begin{array}{l}16 \div 0 \\
0.93\end{array}$ & 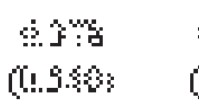 & $\begin{array}{l}0.22 \\
66 \%\end{array}$ & $\begin{array}{l}\text { 0.:16 } \\
\text { क.:H+? }\end{array}$ & $\begin{array}{c}4 \$ 5 \\
41.743\end{array}$ \\
\hline 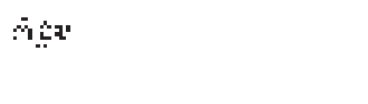 & $\begin{array}{l}-0716 \\
40.94 \%\end{array}$ & $\begin{array}{l}6.63 \\
263^{+}+4+4\end{array}$ & $\begin{array}{l}-100 \% \\
10.23\end{array}$ & $\begin{array}{r}-1,130 \\
(A .34)\end{array}$ & $\begin{array}{r}-0.51] \\
0.16]\end{array}$ \\
\hline \multicolumn{6}{|l|}{ MHARA } \\
\hline T. Mास्स & 4.5 & {$[.7+1$.} & $4 \% \mid 4$ & i] 4 F & 0.991 \\
\hline 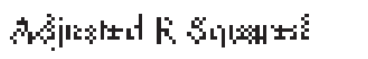 & $\$, 8 \%$ & $0 . \% 5$ & $0 . \leftrightarrow$ & $6.1 \% 0$ & $\$ .80$ \\
\hline 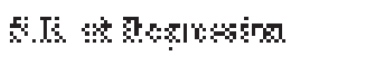 & 3.5 & $\therefore \varnothing 7$ & $\overline{5} \div \overline{7}$ & 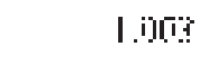 & 4.918 \\
\hline 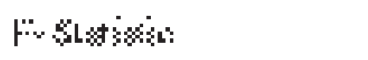 & $|\$ .7|$ & st.112 & artis & 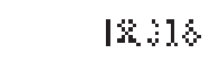 & 205 \\
\hline 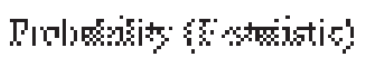 & i] & {$[1 . \% \pi]^{\infty \%}$} & $\ddot{\phi \infty \% \%}$ & {$\left[1.4[1 i]^{\infty \times \infty}\right.$} & 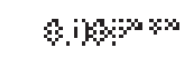 \\
\hline
\end{tabular}

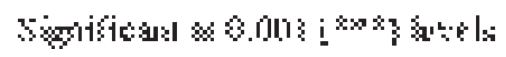




\section{APPENDIX E}

Second regression summary of causal relations of explanatory variables to CAR for spin-off companies, Bursa Malaysia; $n=85$

\begin{tabular}{|c|c|c|c|c|c|}
\hline & \multicolumn{5}{|c|}{ Efrect on Dependent Variahle: CAR intervals } \\
\hline \multicolumn{6}{|c|}{$\begin{array}{c}\text { Coefnitients } \\
\text { (t-values) }\end{array}$} \\
\hline & -1 to 0 & 0 & 0 to +1 & -1 to +1 & -5 to +5 \\
\hline \multicolumn{6}{|l|}{ Variables } \\
\hline Focus & $\begin{array}{c}0.743 \\
(0.808)\end{array}$ & $\begin{array}{c}0.852 \\
(0.967)\end{array}$ & $\begin{array}{l}0.563 \\
(0.619)\end{array}$ & $\begin{array}{c}0.768 \\
(0.809)\end{array}$ & $\begin{array}{c}0.603 \\
(0.688)\end{array}$ \\
\hline Tax & $\begin{array}{c}0.632 \\
(0.757)\end{array}$ & $\begin{array}{l}0.721 \\
(0.796)\end{array}$ & $\begin{array}{l}0.590 \\
(1.612)\end{array}$ & $\begin{array}{c}0.549 \\
(0.619)\end{array}$ & $\begin{array}{c}0.742 \\
(0.865)\end{array}$ \\
\hline Capitalization & $\begin{array}{c}2.065 \\
\left(2.643^{* * * \cdots}\right)\end{array}$ & 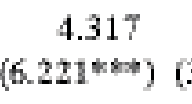 & $\begin{array}{c}2922 \\
\left(3.643^{k * *}\right)\end{array}$ & $\begin{array}{c}1.045 \\
\left(1.612^{\star}\right)\end{array}$ & $\begin{array}{c}1.303 \\
\left(1.825^{*}\right)\end{array}$ \\
\hline \multicolumn{6}{|l|}{ Mode } \\
\hline $\mathrm{R}$-squared & 0.635 & 0.856 & 0.759 & 0.560 & 0.408 \\
\hline Adjusted R Squared & 0618 & 0.821 & 0.732 & 0.477 & 0.384 \\
\hline S.E. of Regression & 11.891 & 16.334 & 10.930 & 12.681 & 8.064 \\
\hline F× batatistic & 41.492 & 42.203 & 11.347 & 10.806 & 16.07 \\
\hline Probability (F-statistic) & $0,000^{k * k}$ & $0,000^{4 k \psi}$ & $0.0000^{* 1 * 4}$ & $0,000^{* k *}$ & $0.000^{k+4}$ \\
\hline
\end{tabular}

Significant at $0.05\left({ }^{*}\right)$, and $0.001\left({ }^{* * *}\right)$ levels. 


\section{APFivis}

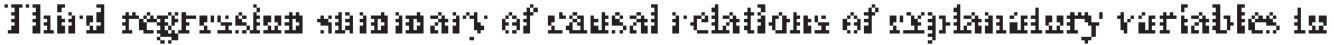 tra

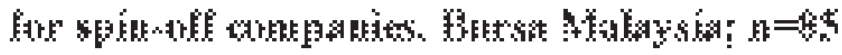

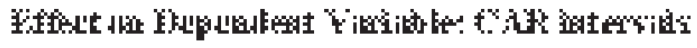

\begin{tabular}{|c|c|c|c|c|c|}
\hline \multicolumn{6}{|c|}{ 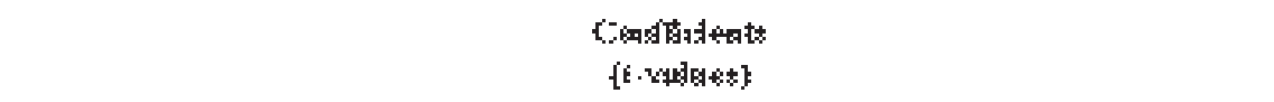 } \\
\hline & : Is ij & 6 & i] & $43 \sin : 8$ & $\therefore 5: \bar{s}$ \\
\hline \multicolumn{6}{|l|}{ 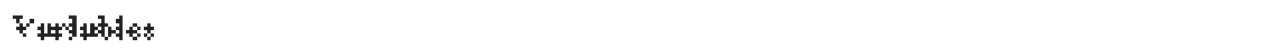 } \\
\hline Y+iss & $\begin{array}{c}1.636 \\
10.277\end{array}$ & $\begin{array}{l}\text { किष } \\
\text { क. dist }\end{array}$ & $\begin{array}{c}{[.45} \\
i \infty .24]\end{array}$ & 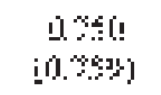 & 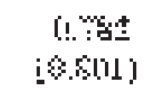 \\
\hline Ta: & $\begin{array}{c}8.62 \\
4.42\}\end{array}$ & 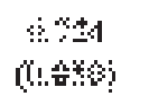 & $\begin{array}{l}0.4 \mathrm{~J} \\
6.639\end{array}$ & 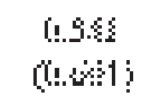 & 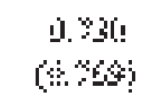 \\
\hline$A_{\mathrm{s}}$ & $\begin{array}{c}3+41 \\
(x, y+4+5\end{array}$ & $\begin{array}{l}0.53 \\
0.918)\end{array}$ & $\begin{array}{l}\text { क.t+2 } \\
0.60 \%\end{array}$ & 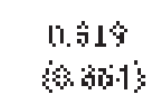 & $\begin{array}{c}\text { Ats } \\
\text { ton }\end{array}$ \\
\hline 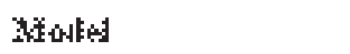 & & & & & \\
\hline X. & 4.36 & i]. .5 & {$[.87]$} & $\$ \pi$ & $\theta \times 4 i]$ \\
\hline 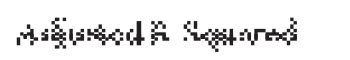 & 1...5:3 & 064 & 8.89 & $\diamond \leftrightarrow$ & ए.\$\% \\
\hline 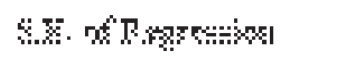 & $2 \mathrm{Bil}$ & $2+44$ & 273 & 3.73 & $3 . \$ 11$ \\
\hline 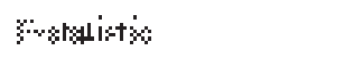 & $2+535$ & 13.75 & $.5 .900^{\circ}$ & 80.00 & $2+412$ \\
\hline 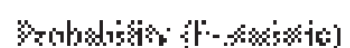 & 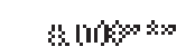 & tolution: & 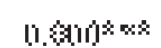 & 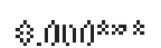 & 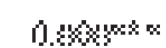 \\
\hline
\end{tabular}

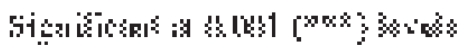

${ }^{1}$ Based on the IFC's Emerging Markets Data Base for a recent period, a commonly held view is emerging stock markets are characterized by high returns and high volatility. Malaysian market is such a market and is ranked among the top-20 or thereabout, and is among the 65-odd emerging markets. It is ranked in the financial press as being among the top five in terms of its desirability for cross-border investments.

${ }^{2}$ The World Bank defines a developing country as one having a per capita GNP that would place it in the lower or middle-income category; a developing country had an annual per capita GNP less than about US\$10,000. Capital markets in such a country would be named an emerging market. The capital market is ranked by OECD in 1999 report as among the top-20 investible market.

${ }^{3}$ Two stock exchanges, the then Kuala Lumpur Stock Exchange (KLSE) and Malaysian Exchange of Securities Dealing and Automated Quotation Bhd (MESDAQ) had merged to form Bursa Malaysia. KLSE was incorporated in 1976 and MESDAQ was incorporated in 1997.

${ }^{4} \mathrm{New}$ foreign and domestic investment played a significant role in the transformation of this economy. Manufacturing share increased from 13.9\% (1970) to 34\% (2005) as agriculture declined from $42.7 \%$ to under 7\% over the same period: see 2005 Bank Negara Malaysia Annual Report.

${ }^{5}$ After nearly two decades of strong economic growth averaging 8.7 percent annually, the financial 
crisis had long-lasting impact by halving the growth prospect, when the regional financial crisis of 1997-8 swept the region. The GDP suffered a sharp 7.5\% contraction in 1998: it rebounded in 1999 to grow by $5.6 \%$.

${ }^{6}$ IRS Section 355 includes four key requirements for tax-free treatment: Controlled corporation; Securities distribution; Active businesses; and Not a distribution device. Treasury regulations Section 1,355-2 adds two additional requirements: Business purpose; and Continuity of interest. See Appendix A for details.

${ }^{7}$ Prior to 1995, Capital Issues Committee (CIC) and the Foreign Issues Committee were reviewing. CIC was set up in 1968 by the Minister of Finance to ensure an orderly development of the capital market by regulating the issue of securities by public companies and the listing of such securities on Bursa Malaysia including spin-offs. See the requirements for spin-offs in Appendix A.

${ }^{8}$ It was possible to use distribution of bonus shares as consideration to save RPGT on selling of land together with the real property companies before 1977 .

${ }^{9}$ Despite the widespread use of the named variables in this section, there is still no agreement among the researchers on the factors influencing the Spin-off effect. We place on record this list as the possible starting point for this study.

${ }^{10}$ In this study we chose day -100 to day +50 as the window for analysis for the parent company because pre- and post spin-off days are needed for testing a hypothesis. Also, in a less matured market with approval procedures that take longer time than in the matured market, we needed to go back to about 4.5 months to observe the price effect.

${ }^{11}$ The argument offered here is that there is an absence of tax motivation for spin-off in the Malaysia compared to the United States. See Appendix A and B for the legal framework in these countries.

${ }^{12}$ The results of these second and third regressions are produced in Appendices C, D, E and F. 